\title{
UM NOVO HORIZONTE PARA A EDUCAÇÃO1
}

\author{
A NEW HORIZON FOR EDUCATION
}

Ivo Tonet ${ }^{2}$

Universidade Federal de Alagoas - UFAL

\begin{abstract}
Resumo
É inegável que a humanidade está vivenciando uma crise de extrema gravidade. Crise que tem sua razão mais profunda na própria dinâmica de reprodução do capital e que põe a humanidade diante do dilema: ou superação do capitalismo e construção de uma sociedade efetivamente livre, comunista, ou intensificação cada vez mais crescente da barbárie. Nesse sentido, é um absurdo colocar como objetivo o aperfeiçoamento dessa ordem social. Infelizmente, a maioria das teorias, inclusive no campo da educação, ao defender como objetivo maior a ampliação da cidadania e da democracia, está levando água, independente da intenção, à busca da humanização dessa ordem social. Nossa intenção nesse texto é demonstrar que a emancipação humana, só possível em uma sociedade comunista, deve ser posta como objetivo de todos aqueles que, no processo educativo, defendem uma forma de sociabilidade na qual todos os indivíduos possam ser efetivamente livres e, com isso, realizar de forma ampla as suas potencialidades.
\end{abstract}

Palavras-chave: Educação; Barbárie; Emancipação Humana.

\begin{abstract}
It is undeniable that humanity is experiencing a crisis of extreme gravity. Crisis that has its deepest reason in the very dynamics of reproduction of capital and that puts humanity in the dilemma: either to overcome capitalism and build an effectively free, communist society, or to steadily increase the intensification of barbarism. In this sense, it is absurd to set as objective the perfection of this social order. Unfortunately, most of the theories, including in the field of education, when defending as a larger goal the expansion of citizenship and democracy, are leading, regardless of intention, to the search for the humanization of this social order. Our intention in this text is to demonstrate that human emancipation, only possible in a communist society, should be set as the goal of all those who, in the educational process, defend a form of sociability in which all individuals can be effectively free and, with this, realize their full potential.
\end{abstract}

Keywords: Education; Barbarism; Human Emancipation.

\footnotetext{
${ }^{1}$ Esse texto baseia-se em uma conferência pronunciada no I Congresso de Ontologia do Ser Social e Educação, promovido pelo IBILCE - UNESP - São José do Rio Preto em nov/dez 2007.

2 Professor de Filosofia do Instituto de Ciências Humanas, Comunicação e Artes da Universidade Federal de Alagoas. Doutor em Educação.
} 


\section{INTRODUÇÃO}

Este debate e outros dos quais temos participado estão sendo feitos em um momento histórico muito particular. Em outro momento o tom deles, com certeza, seriam muito diferentes.

Uma das características desse momento, a nosso ver, é que a humanidade está atravessando um período profundamente contrarrevolucionário. Um período em que sucessivas vitórias do capital ao longo desses últimos 150 anos e, especialmente nas últimas décadas, parecem ter deixado o capitalismo como única alternativa para humanidade. E quando a maioria da intelectualidade sustenta que esta é a única alternativa não é por acaso. É por que parece que, de fato, a realidade cotidiana, o mundo em que vivemos, não põe outra possibilidade. Ainda mais porque a maioria das pessoas, por uma série de circunstâncias que não cabe abordar aqui, pensa que com o desmoronamento daqueles países, daquelas sociedades que se diziam socialistas, acabou a alternativa que se chamava socialismo. Então, parece que, de fato, a única alternativa, para aqueles que não querem a selvageria do capitalismo atual, seria o aperfeiçoamento da ordem vigente. Este aperfeiçoamento se chama instauração, o mais plena possível, da cidadania e da democracia. Esta parece ser a única alternativa real.

Isto, certamente, configura uma situação histórica muito difícil. Para desmistificar estas idéias, seria necessário fazer, aqui, uma exposição mais ampla da questão do método de modo a mostrar como os fundamentos metodológicos instaurados por Marx permitem ultrapassar essa empiricidade coisificada e fragmentada e vislumbrar a possibilidade - real, embora não inevitável - de superação dessa forma de sociabilidade. Na impossibilidade de fazer essa exposição, fica, aqui, apenas aludida a importância dessa questão.

\section{TRÊS TESES}

Para deixar as coisas, de início, bem claras, esclarecemos que vamos defender três teses.

Primeira tese: Cidadania e democracia, que compõem a emancipação política, são uma coisa muito boa, um progresso para a humanidade, mas são uma forma de liberdade essencialmente limitada. Não apenas topicamente limitada, mas essencialmente limitada. Mais ainda: elas são, pela sua própria natureza (sobre a qual vamos falar depois), ao mesmo tempo, expressão da desigualdade social e condição 
de sua reprodução; portanto não são caminhos para a superação da exploração do homem pelo homem.

Segunda tese: A emancipação humana é uma forma de liberdade radicalmente diferente e superior à liberdade expressa pela emancipação política, e é a forma mais autêntica de liberdade que o ser humano pode ter.

Portanto, aí está a terceira tese: qualquer educação, qualquer atividade educativa, que se pretenda emancipadora no sentido forte do termo, não no sentido idealista, tem que estar conectada, com todas as mediações necessárias, com a emancipação humana, não com a emancipação política.

Trabalhar para formar cidadãos é trabalhar para formar pessoas que vivam dentro dessa sociedade regida pelo capital, conformem-se com ela e limitem-se a melhorá-la. Trabalhar pela emancipação humana é conectar nossa atividade com a perspectiva da superação radical do capital.

Outra questão conjuntural importante: não há três alternativas para a humanidade. Só há duas. E a realidade, tanto histórica do capitalismo, quanto cotidiana, mostra cada vez mais isso: ou a barbárie cada vez mais intensa do capitalismo, ou a superação dele em direção à emancipação humana, ao comunismo. Não há terceira alternativa (obviamente, a extinção da humanidade, embora sendo uma possibilidade, não é considerada uma alternativa). E, no entanto, a maioria dos intelectuais e a maioria dos movimentos de esquerda está procurando uma terceira alternativa, está defendendo uma terceira via. Uma alternativa que não existe. Está procurando, não importa o nome que seja dado, o aperfeiçoamento dessa ordem social. Este é um aspecto trágico do nosso momento histórico. Nós temos que levar em conta isso, sabendo que a história é um movimento, é um processo, não é algo estático nem a eterna repetição do mesmo. O amanhã poderá ser melhor ou pior. Depende do que os homens fizerem. Afinal, a história é feita pelos seres humanos, pelos homens, não é feita nem por Deus nem pela Natureza.

Dito isso, para entrar na problemática da Educação, o que se observa é que grande parte dos teóricos da Educação, e me refiro aqui aos mais conhecidos, não só do Brasil, mas também da área internacional, toma a cidadania como sinônimo de liberdade, como se ser cidadão fosse participar da forma de sociedade mais elevada possível. Sempre aperfeiçoável, mas não ultrapassável. Esta forma de sociabilidade comporia um patamar indefinidamente aberto ao melhoramento. Não caberia, portanto, falar em outra forma, mais aperfeiçoada de sociedade. Quem conhece Marilena Chauí, 
que é uma expoente dessa maneira de pensar, quem leu o livro Convite à Filosofia, sabe que nos últimos capítulos ela diz exatamente isso. Ela afirma que a democracia é o único sistema verdadeiramente histórico, porque sempre aberto. Ele permite criar direitos, melhorar direitos, corrigir direitos, está indefinidamente aberto para 0 progresso da humanidade. E, se vocês lerem autores como Libâneo, Gadotti, Frigotto e muitos outros, verão que todos eles entendem a cidadania como simplesmente sinônimo de liberdade. E até, observe-se como a coisa é complicada, queremos enfatizar que falamos isso com todo respeito, porque consideramos esse autor o que há de melhor e mais revolucionário na teoria educacional brasileira. Até Saviani, num determinado texto, faz uma louvação à cidadania sem apontar as suas limitações intrínsecas.

Ao que nos parece, a maioria desses intelectuais da área da Educação absorveu o conceito de cidadania como sinônimo de liberdade, de maneira inteiramente acrítica. Isso foi num momento histórico determinado. Por volta de 1970, mais ou menos, com toda aquela crítica ao chamado socialismo do Leste Europeu, que tinha todos aqueles defeitos, todas aquelas deformações. Então, pareceu que a proposta da revolução deveria ser substituída pela proposta da reforma, gradual, lenta e especialmente democrática.

A conclusão era de que a revolução, que era sinônimo de revolução de tipo soviético, sempre levava à ditadura, sempre levava àquela situação perversa, em todos aqueles países. Se, de fato, a revolução era isso, então, o que é que sobraria? Apenas a ampliação da democracia, que era exatamente o que estaria faltando nas revoluções de tipo soviético. Seria a ampliação dos espaços democráticos, o que era chamado de socialização do poder político. E todo mundo entrou por esse caminho: cidadania e democracia compõem o espaço indefinidamente aperfeiçoável da liberdade.

A maioria dos teóricos da educação bebeu de fontes filosóficas ou de cientistas políticos: Claude Lefort, Castoriadis, uma certa leitura de Gramsci, os teóricos italianos do eurocomunismo. Mas não se preocupou, nem a teoria marxista de que dispunham Ihes dava suporte para fazer uma crítica dessa problemática e acabaram tomando esse conceito como óbvio.

Então toda a educação foi pensada no sentido de formar o cidadão. Mas esses teóricos de esquerda, para distinguir o seu conceito de cidadania, também largamente utilizado pelos conservadores, enfatizaram que formar cidadãos significava formar pessoas participativas, que têm consciência dos seus direitos, que lutam pelos seus 
direitos, que não aceitam as coisas passivamente. Em suma, formar cidadãos críticos. Libâneo é muito explícito nisso. Ele diz que é preciso formar trabalhadores como cidadãos críticos. O que é absolutamente uma contradição nos termos. Trabalhador explorado é cidadão.

E, mesmo sendo crítico, ele não deixa de ser explorado, logo, não é efetivamente livre. Ser crítico, no sentido radical do termo, é ser revolucionário. Esse é o único sentido efetivamente possível de ser crítico no sentido marxiano do termo: ser revolucionário, não ser cidadão. Mas eles pensam que formar cidadãos é formar pessoas que não estão aceitando os desmazelos do capitalismo, com toda essa violência e desigualdade social extremadas, mas querem lutar por uma sociedade "mais justa", "mais humana", "mais igualitária". Ora, mais justa, mais humana, mais igualitária tem na Suíça, tem na Suécia quando se compara com o Brasil ou com o Burundi. O problema não é mais justa, mais livre e mais igualitária. É simplesmente justa, livre e igualitária. E esta só é possível para além do capitalismo.

Então, aquele foi um momento histórico em que se rebaixou o horizonte, se perdeu o horizonte revolucionário, se perdeu a perspectiva da emancipação humana e se tomou o caminho da emancipação política como se ela fosse a única e melhor alternativa, sendo o resto apenas utopia.

A nosso ver, aí foi a debandada geral da inteligência, no caso aqui específico, da teoria educacional. Por isso mesmo, entendemos que é preciso voltar a retomar essa questão pela raiz. Vamos examinar, então, o que é cidadania, o que é emancipação humana e qual é a conexão entre educação, cidadania e emancipação humana.

Voltamos rapidamente à questão do método, só para deixar bem claro. Para abordar qualquer fenômeno social, pelo menos dois procedimentos são fundamentais, do ponto de vista metodológico marxiano. Primeiro: buscar a gênese do fenômeno que se quer entender. Gênese histórico-ontológica acentue-se, não apenas histórica. Infelizmente não temos tempo para explicar em detalhes o que é histórico-ontológico. Porque não estamos simplesmente falando histórico, mas histórico-ontológico. Ainda assim, algumas coisas devem ser ditas.

Há um livro bastante alentado chamado História da cidadania, organizado por Jaime Pinsky e Carla B. Pinsky. Podemos lê-lo e chegar ao fim pensando que se sabe o que é cidadania. No entanto, chegamos ao fim com uma ideia falseada do que é cidadania, porque é uma história social do que é cidadania, no máximo sociológica, no máximo de ciência política, mas não é histórico-ontológica. 
O que é uma abordagem histórico-ontológica? É uma abordagem que parte do pressuposto de que o ser social é uma totalidade articulada de partes cuja matriz fundante é o trabalho. Por isso vai buscar, ao mesmo tempo em que a gênese histórica, também os fundamentos para entender onde, quando e por que surgiu aquele fenômeno.

Segundo: compreender a função social que aquele fenômeno exerce. Como isto poderia ser confundido com funcionalismo, gostaríamos de deixar bem claro que aqui função social significa a função que determinada atividade humana, determinada dimensão social, tem na reprodução do ser social.

Então, na medida em que se toma essa categoria da cidadania e se rastreia o seu surgimento, a partir de que solo social ela se originou, com que função social emergiu, podemos ver qual é a natureza dela, quais são as suas possibilidades e também quais são os seus limites. Esse é um procedimento histórico-ontológico porque faz emergir o sentido essencial daquele fenômeno. Certamente, todo aquele material histórico, todos aqueles fatos são interessantes, mas os fatos, sem uma teoria geral do ser social, sem uma ontologia do ser social, falseiam a compreensão dos fenômenos sociais.

Então, se nós procedermos dessa forma, se formos buscar a gênese da cidadania moderna, onde é que vamos encontrar a raiz dela? Na descrição de como ela nasceu e na sua história? Certamente, isso é necessário. Mas, não é, de modo nenhum, suficiente. Precisamos voltar ao pressuposto da teoria do ser social, da ontologia do ser social, começar do ato fundante do ser social? Por quê? Porque é a partir dele que se configura o mundo social. Porque ele é o ato que funda, que dá origem ao ser social. É a partir dele que se dá a passagem do ser natural para o ser social. E este ato de trabalho vai permanecer sempre como ato fundante de qualquer forma de sociabilidade humana.

Isto é importante: toda forma de sociabilidade humana tem, sempre, como seu fundamento ontológico, uma determinada forma de trabalho. Então, se nós quisermos ir à raiz, compreender qualquer fenômeno social, teremos que chegar até à forma como os homens se organizam para produzir os bens materiais necessários à sua existência, vale dizer, como trabalham. Levando em conta, evidentemente, todas as mediações necessárias. Se nós queremos compreender a essência do que é cidadania, temos que ir à raiz, que não está nela, mas na forma de trabalho concreta que lhe dá origem. Esta forma de trabalho é a forma de trabalho moderna. 
Qual é a forma de trabalho que constitui o pilar da sociedade moderna? É a compra e venda de força de trabalho, seja ela direta seja indireta. É por meio da compra e venda da força de trabalho que se geram todas as categorias que perfazem a sociedade capitalista.

Vamos, então, examinar um pouquinho este ato fundante da sociabilidade capitalista. A título de esclarecimento, vale observar que contrato de trabalho, ao qual nos referiremos, não é o chamado contrato social. O contrato de trabalho é aquele que celebram entre si o capitalista e o trabalhador. Este contrato exige, para sua efetivação, dois sujeitos que tenham pelo menos três qualidades fundamentais: que sejam livres, iguais e proprietários. Só sujeitos que tenham no mínimo essas três qualidades podem fazer esse contrato. Ora, este contrato, na medida em que é feito, o que aparenta? Que, de fato, estes dois sujeitos são livres, porque não são jurídica e politicamente obrigados, são iguais, porque trocam equivalentes e são proprietários, cada um de alguma coisa, um da força de trabalho e o outro do capital.

Vamos ficar um pouco nesta parte para depois voltar a retomar o ato fundante. O desdobramento subsequente disto é a historia da emancipação política moderna. A emancipação política moderna nada mais é do que a transformação de todos os indivíduos em cidadãos; a superação dos privilégios medievais; a superação da concepção medieval de que a desigualdade era natural pela concepção de que a igualdade é natural.

Contudo, essa igualdade existente naquele contrato carrega em si determinados elementos que vão convertê-la em desigualdade, uma vez que cada um busca a satisfação dos seus interesses individuais. A correção dessa desigualdade é feita exatamente pelos direitos de cidadania e pelas instituições democráticas do Estado. Estes direitos de cidadania, este conjunto de instituições democráticas, dos quais nós podemos fazer história a partir do século $\mathrm{XV}$, se quisermos ir à raiz mais longínqua, constituem a história da luta entre capital e trabalho. É po meio disso que se constituem esse conjunto de direitos e deveres e estas instituições, nos quais nós vivemos hoje. De uma forma extremamente complicada e complexa, são desdobramentos dessas três qualidades fundamentais: igualdade, liberdade e propriedade.

Porém, quando examinamos esse ato na sua efetividade, quando vamos para a fábrica, o que é que percebemos? Que, de um lado, está o patrão e, do outro, o trabalhador. Mas, aí, no andar da carruagem, o que se vê é que o patrão é mais igual, 
mais proprietário e mais livre, porque não é o trabalhador que explora o patrão; é o patrão que explora o trabalhador e, portanto, apropria-se da maior parte da riqueza produzida pelo primeiro. Aí a desigualdade social se põe, e ela, ao contrário do que muita gente pensa, do que parece na imediaticidade, não é um defeito do capitalismo. Ela faz parte da essência dele, é da natureza dele.

Onde há exploração do homem pelo homem sob a forma de trabalho assalariado há desigualdade social, porque a desigualdade social (no capitalismo) é gerada neste ato de compra e venda de força de trabalho e na sua efetivação. Ela pode ser minorada, mais ou menos, pode adquirir formas diferentes, mas não pode ser eliminada dentro dessa ordem social. Produzir desigualdade social é tão natural para o capitalismo como produzir seda para o bicho da seda.

Esta lógica do capitalismo não pode ser controlada. Aliás, quem leu Mészáros sabe bem disto. Esta lógica que se instaura na fabrica é incontrolável, porque a autorreprodução é uma exigência interna, essencial, do capital. E, para evitar malentendidos, é bom que se esclareça o que significa controlar. Significa impor ao capital uma lógica que não seja a sua própria. Qual é a lógica do capital? Produzir visando a sua própria reprodução. Capitalista quer ganhar dinheiro e para ganhar dinheiro tem que explorar. Capitalista bonzinho, que não quer explorar ninguém, vai virar proletário. Não há possibilidade de fugir. O capital tem que produzir para trocar; os produtos têm que virar mercadoria.

Então, voltando à nossa questão, se tomamos aquele ato fundante do sistema capitalista, que é a compra e venda da força de trabalho, temos lá a produção, ao mesmo tempo e incindivelmente, numa ponta, da desigualdade social e, na outra ponta, da igualdade formal. Essas duas coisas não são desconectáveis. A esquerda democrática (à qual depois vamos nos referir) quer desconectar, mas não são desconectáveis. Embora em formas muitíssimo diversas, uma não pode existir sem a outra.

O capitalismo em sua plenitude não pode funcionar sem uma dose de cidadania e democracia, sem a emancipação política. A emancipação política é a expressão dessa desigualdade social típica do capitalismo. Então, temos numa ponta a desigualdade social e na outra a igualdade formal, a liberdade formal e a fraternidade formal, que se chama solidariedade.

Sem uma certa dose, que pode ser maior ou menor, de cidadania e democracia o capitalismo não funciona, porque o capital é um regime concorrencial. Há 
contradições dentro dele e, por isso, são necessárias certas regras, que devem ser observadas por todos. Então é preciso haver certas folgas que permitam a essas contradições aparecerem, portanto não dá para desconectar, não dá para querer uma sociedade democrática separando simplesmente o capital da lógica do capital.

Em resumo, este ato de compra e venda de força de trabalho gera o valor de troca, a mercadoria, o capital, o trabalho assalariado, a burguesia e o proletariado - as classes sociais típicas do capitalismo - a desigualdade social, etc. É o conjunto de categorias que são necessárias para a reprodução do capital. Na outra ponta desta totalidade, pela dinâmica social, não simplesmente por uma geração espontânea, mas, pela luta social, gera-se este conjunto de direitos civis, políticos e sociais. Mas o que dissemos não é suficiente. Ainda é preciso enfatizar que o aspecto privado, o aspecto da produção da desigualdade social é o aspecto fundamental. Não são dois aspectos colocados no mesmo nível. A desigualdade real é que exige a igualdade formal, não é o contrario. Então a emancipação política é uma exigência da desigualdade real do capitalismo. É porque existe a desigualdade real típica do capitalismo, que é necessária a igualdade formal.

Este é simplesmente o limite da emancipação política. E isto dá para perceber muito claro quando se volta de novo para a fábrica. Na fábrica não tem democracia, quem manda é o patrão. Fora da fábrica tem democracia. Dentro da fábrica o que se tem? Tem o sujeito que está lá trabalhando. Ele é trabalhador e, nesta relação com o patrão, é explorado, mas ele é, ao mesmo tempo, cidadão. O trabalhador assalariado pode perfeitamente ser um cidadão na sua mais elevada expressão, sem nenhuma contradição. A desigualdade e a exploração supõem, aliás, a igualdade formal. Então se tomamos a Suécia, a Suíça, os países mais desenvolvidos, vemos que lá os direitos civis, políticos e sociais estão num grau muito elevado. No entanto, também lá continua a haver exploração dos trabalhadores. É bom lembrar que esses países atingiram um grau de elevação impensável no Brasil e em outros países do chamado terceiro mundo. Não há contradição nisto, mas isso não é um caminho que todos os países vão seguindo, todo mundo vai chegar lá.

Pelo contrário, eles estão lá porque nós estamos cá. Então, essa desigualdade real e a igualdade formal se manifestam naquele que é trabalhador, ao mesmo tempo explorado e cidadão. Ele pode ser cidadão, com amplos e extremamente garantidos direitos civis, políticos e sociais, mas ele não deixa de ser explorado. Desde que ele está nesta relação de compra e venda de força de trabalho, seja direta seja indireta, 
nunca deixará de ser explorado. Portanto, mostra-se também empiricamente que cidadania e democracia não são o contrário do capital; são o reverso da mesma moeda e por mais que sejam ampliadas, jamais vão permitir que os indivíduos se transformem em autênticos integrantes do gênero humano.

No entanto, alguém poderia perguntar o que significa essa integração autêntica ao gênero humano. Isso é muito tranqüilo.

Voltemos um pouco à ontologia do ser social. A análise do trabalho nos permite entender que o ser social é composto de dois polos. O individuo e o gênero. Se examinarmos a animalidade, isso também fica muito claro. Se separarmos qualquer animal dos seus congêneres, veremos que ele vai se desenvolver sem precisar fazer parte do grupo. Os animais não precisam da sociabilidade para desenvolver a sua animalidade porque eles a trazem consigo como uma determinação biológica. Conosco é diferente. Os indivíduos, ou melhor, o ser singular humano, que ainda nem é indivíduo humano propriamente dito, precisa, para se tornar membro efetivo do gênero humano, apropriar-se do patrimônio gerado e posto à disposição da humanidade naquele momento. Isto faz do ser singular um indivíduo pertencente ao gênero humano. É claro que isto é diferente em cada momento histórico. Como nós estamos tratando do mundo atual, hoje é necessário, para que todos nós possamos nos tornar indivíduos humanos, pertencentes ao gênero humano como indivíduos efetivos, ter acesso à riqueza material e espiritual (espiritual no sentido amplo do termo, intelectual, cultural). Toda essa riqueza é necessária para a nossa autoconstrução como seres pertencentes ao gênero humano.

Ora, esta apropriação, e aí é apropriação e objetivação ao mesmo tempo, porque para nos fazermos (objetivar-nos), nós precisamos nos apropriar, esta apropriação supõe uma forma de trabalho completamente diferente daquela que existe hoje. A forma atual do trabalho impede que a maioria das pessoas tenha acesso a toda essa riqueza e aqueles que têm acesso o têm de uma maneira completamente deformada pelas atuais relações sociais. Sob o capitalismo é absolutamente impossível formar indivíduos plenamente humanos e uma autêntica comunidade humana. Portanto, quando se fala em comunidade, em construir uma comunidade solidária, isso é tudo palavreado, porque pela lógica do capital é impossível construir-se uma autêntica comunidade humana entre explorados e exploradores. Isso é absolutamente claro.

Ora, essas categorias são ontológicas; não são uma invenção, uma simples 
construção intelectual. São categorias extraídas do processo social real.

Então, concluindo esta parte. A emancipação política, e isso é de Marx na Questão Judaica, é um grande avanço na história da humanidade sem dúvida nenhuma. É muito melhor ser trabalhador assalariado com direitos civis, políticos e sociais do que ser escravo ou servo. Isso é um avanço da humanidade; é um avanço na forma de liberdade. Mas Marx também diz que esta é a última forma da liberdade numa sociedade onde existam classes sociais. E porque ser uma sociedade de classes, essa forma de liberdade não pode ser integral, efetiva; ela tem um limite insuperável.

Se isto é verdade, então a humanidade está diante de duas alternativas: uma é a barbarização crescente da vida humana, que é isso que todo mundo vê até empiricamente (e isto inclui a emancipação política), a outra, uma autêntica comunidade humana (que é sinônimo de emancipação humana, de comunismo). Nós temos, então, que começar a pensar, começar a falar, começar a teorizar sobre a perspectiva da emancipação humana e não da cidadania.

Mas a primeira coisa que precisamos ter claro é o que é emancipação humana. Isso porque muitas palavras são usadas sem o devido cuidado e rigor. É que nem a palavra socialismo, todo mundo fala, mas todo mundo tem um entendimento diferente. Muita gente acha que continua havendo socialismo em Cuba, que houve e há socialismo em Cuba. Quando perguntamos o que é socialismo? A resposta é que socialismo é igualdade social, é planejamento econômico centralizado, é supressão da propriedade privada, enfim, é uma sociedade que parece estar caminhando no sentido de uma igualdade social maior. Ora, isso nada tem a ver com socialismo.

Vamos voltar ao velho Max e vamos voltar ao ato fundante do ser social. O que é que ele diz? E não somos nós que dizemos nem sequer Lukács, está lá nos Manuscritos econômico-filosóficos, está lá no Capital, com todas as letras, que o ato de trabalho como criador de valores de uso é uma lei eterna da existência humana. Se o ato de trabalho é o ato fundante do ser social e de qualquer forma de sociabilidade, então, para poder pensar uma forma de sociabilidade para além do capital, temos que buscar qual é a forma de trabalho que vai fundamentar uma outra sociedade. $E$ isto tem que ser real, não pode ser uma invenção da cabeça. Se há uma coisa que Marx sempre frisou é que nós temos que ter o pé no chão. Quem leu a Ideologia Alemã (1986, p. 26) sabe disso: Os pressupostos de que partimos não são arbitrários nem dogmas. São pressupostos reais (...). São os indivíduos reais, sua ação e suas condições materiais de vida, tanto aquelas por eles já encontradas, como as produzidas por sua 
própria ação.

E mais, diz ele em $O$ Capital que, se as condições de possibilidades do comunismo não estivessem inscritas na sociedade capitalista, não adiantaria ficar falando em comunismo, porque durante milênios se falou sobre comunismo, desde o Paraíso Terrestre, desde as comunidades primitivas. Platão falava de comunismo. Aquilo era utopia de fato. O que Marx pensa não é utopia, é uma possibilidade real. Possibilidade, não inevitabilidade, mas possibilidade real.

Então, qual é a forma de trabalho que pode dar sustentação, fundamento a uma autêntica comunidade humana? Só pode ser a forma de trabalho mais livre possível. E qual é a forma de trabalho mais livre possível? A forma de trabalho em que todo mundo contribua e na qual ninguém explore ninguém.

Isso Marx chama de trabalho associado ou associação livre dos produtores livres. Mas deve ficar claro que trabalho associado não é trabalho cooperativo, não é trabalho solidário, economia solidária, e também não é trabalho voluntário. Trabalho associado é uma categoria muito precisa. É a forma de trabalho em que os produtores dominam livre, consciente, coletiva e universalmente o processo de produção. Repito, porque isso é fundamental: trabalho associado é a forma de trabalho em que os produtores dominam livre, consciente, coletiva e universalmente o processo de produção. E, na medida em que a produção é a base da sociedade, eles também poderão ser os senhores do conjunto do processo social. Ora, esse domínio significa que os homens possam partir das suas necessidades (não daquelas da reprodução do capital) e estabelecer o que deve ser produzido, em que condições deve ser produzido e como deve ser repartida essa riqueza.

Se, então, examinarmos o processo histórico, veremos que a humanidade já foi levada, pelo próprio capitalismo, a ser uma universalidade, mesmo que estranhada. Hoje a humanidade é uma aldeia global, o que mexe lá na Wall Street mexe em todo canto do mundo. De maneira diferente, mas mexe. Não tem mais nenhum um pedacinho fora dessa aldeia global. A humanidade é uma universalidade real, ainda que estranhada, então não dá para construir um país emancipado, um só país comunista isolado. Isso não faz nenhum sentido, porque a lógica do capital é universal. Ou se desmonta essa lógica universal ou não dá para construir uma forma de sociedade para além do capitalismo.

Esse trabalho supõe a universalidade, e o trabalho associado supõe também aquilo que Marx disse na Ideologia Alemã: um alto grau de desenvolvimento das forças 
produtivas. Não é possível haver trabalho associado, neste sentido de Marx, onde há atraso, baixo desenvolvimento das forças produtivas, carências, enfim, onde há miséria. $O$ trabalho associado supõe que se produzam bens necessários à satisfação das necessidades de todos naquele momento histórico. Supõe uma forma de produção voltada para o valor de uso abundante, não para o valor de troca.

Se entrar em cena esse trabalho associado, extinguem-se o capital, o trabalho assalariado, a exploração do homem pelo homem, as classes sociais, a desigualdade social, todas essas categorias do capitalismo, porque não faz sentido, não cabe a exploração do homem pelo homem onde todos trabalham, onde com este trabalho é possível produzir aquilo que atende as necessidades humanas e em quantidade e qualidade adequadas. E frise-se que não é apenas quantidade, é também qualidade adequada. E isso permite, então, que a humanidade se torne uma autêntica comunidade humana, uma vez que já não existem classes sociais.

Se isso parece utópico, então vale a pena examinar os dados à disposição atualmente, inclusive de órgãos insuspeitos, que não são marxistas, não são comunistas. Eles dizem claramente que com a tecnologia média de hoje seria possível, pegando só a questão da alimentação, produzir alimentos suficientes para saciar plenamente a fome de toda a humanidade. Se não se sacia não é por falta de tecnologia, não é por falta de conhecimento científico, é por outro fenômeno que se chama relações sociais. E relações sociais fundadas na propriedade privada.

Isso é uma possibilidade real, não é uma fantasia do Marx. Há 200 anos não era possível. Era, digamos, uma aspiração generosa, mas não era possível, uma vez que não existia capacidade de produzir riqueza em abundância. Hoje é plenamente possível, mas para isso é preciso acabar com o capitalismo, então a humanidade resolve esse problema tranquilamente.

Gostaria de deixar bem clara essa questão da necessidade de uma base material altamente desenvolvida, porque toda a discussão sobre o socialismo, sobre o comunismo foi deformada a partir do mau entendimento dessa problemática. Por trás dessa discussão, às vezes de maneira não explicitada, está a ideia de que os países ditos socialistas eram de fato socialistas, de que aqueles países, de alguma forma, embora com todas as imperfeições, problemas e obstáculos, estavam no caminho do socialismo.

Até Lukács, um dos autores que mais contribuiu para resgatar o caráter radicalmente crítico e revolucionário do marxismo, enganou-se a respeito disso. Até o 
fim da vida ele acreditava que a União Soviética estava no caminho do socialismo. Acreditava que era possível democratizar o país e retomar o caminho do socialismo.

A discussão toda está falseada quando se começa por admitir que, do ponto de vista econômico, aqueles países, embora com todos os problemas, estavam construindo as bases materiais do socialismo. Começa-se com um argumento que é imprestável, porque estatização, nacionalização, planejamento econômico centralizado, supressão jurídico-política da propriedade privada, tudo isso nada tem a ver com socialismo. Então começa-se a dizer: aquilo era socialismo, embora com problemas. O que faltava? Faltava exatamente o que toda essa teorização "descobriu": a socialização do poder político, a democracia e a cidadania. Logo, todo o esforço foi despendido na sustentação de que cidadania e democracia são valores universais e não particulares e que, por isso mesmo, à socialização da economia, já em andamento, dever-se-ia adicionar a efetivação da cidadania e da democracia. Aí sim haveria socialismo, mas um socialismo democrático.

Esqueceu-se, e até Lênin também, de alguma forma, esqueceu de começar pelo exame da categoria que funda qualquer forma de sociabilidade, que é o trabalho. No caso do socialismo, do trabalho associado. E esqueceu-se de que Marx afirmou que uma revolução proletária, comunista, que leve à emancipação humana, tem que ser uma revolução política com alma social e não uma revolução social com alma política. Essa é uma distinção fundamental.

Essa importantíssima distinção se encontra num texto de Marx chamado Glosas críticas ao artigo O rei da Prússia e a reforma social. De um prussiano. Quem não leu, deveria ler porque é um texto, de 1844, belíssimo e importantíssimo. Ele demole toda a filosofia e toda a ciência política desde Aristóteles até o momento, porque mostra o que é o Estado, como nasce o Estado e qual é a função essencial do Estado. Também mostra qual a relação entre a economia e a política, deixando claro que o fundamento da vida social está na primeira e não na segunda. E ainda mostra que todas as revoluções até então foram revoluções sociais com alma política, ou seja, mantiveram a exploração do homem pelo homem, a dominação do homem pelo homem. E conclui afirmando que a revolução proletária tem que ser uma revolução política com alma social.

O que é uma revolução política? É a quebra do poder político das classes dominantes. Sem quebrar o Estado (poder político), e enfatize-se, quebrar, não simplesmente tomar. Não é possível mudar radicalmente a lógica do capital. Marx já 
deixava bem claro que não é Estado nenhum, nem partido nenhum que vai fazer a libertação da classe trabalhadora. É ela mesma ou ninguém. Pode haver inúmeras mediações, mas é a classe trabalhadora que deve liderar o processo de transformação radical da sociedade. Enquanto ela não assumir esta tarefa, organizar-se, tiver consciência e for à luta, a revolução não se realizará.

Não é Estado nenhum que vai construir o socialismo. O que é que aconteceu depois das revoluções soviética, chinesa, vietnamita, cubana? O Estado recebe a tarefa de construir as bases materiais para o socialismo. Isso não faz sentido nenhum, porque só é possível construir essas bases, ou seja, produzir riqueza em abundância, em situação de atraso, com base na exploração dos trabalhadores, supostamente aqueles que deveriam usufruir do socialismo.

Há duas tarefas, que são conjugadas, para realizar a revolução proletária: a quebra do poder político do Estado burguês e a instauração do trabalho associado. Os trabalhadores devem tomar nas suas mãos e dirigir a produção em função das necessidades humanas, não mais da reprodução do capital. É isto que elimina o caráter de mercadoria dos produtos, mas é importante acentuar que não se trata simplesmente de autogestão da produção pelos trabalhadores. Trata-se de mudar radicalmente o processo de produção, tendo como objetivo o valor de uso e não o valor de troca. É certo que toda essa mudança será um processo lento, que implicará um período de transição entre uma forma de trabalho e outra. Contudo, o que é importante realçar é que o trabalho associado, vale dizer, o controle livre, consciente e coletivo e universal do processo de produção por parte dos produtores, deve entrar em cena desde o início, porque sem ele é impossível avançar no sentido do comunismo.

Marx já afirmava isso na Ideologia Alemã, que é de 1845-46. Ele dizia que se o processo revolucionário não caminhasse nesse sentido de quebrar o poder político da burguesia e instaurar o trabalho associado toda a sujeira anterior se reporia. A instauração desse domínio livre, consciente, coletivo e universal dos produtores sobre o processo de produção é absolutamente necessária para que se extingam o capital e todas as suas categorias.

Isto deveria levar os teóricos a voltar ao que é fundamental. E o fundamental é que o trabalho é a base da sociedade. É a partir do exame da questão da forma do trabalho que se pode fazer uma crítica consequente de todas as tentativas de revolução socialistas e fundamentar corretamente um processo revolucionário. Somente o trabalho associado pode garantir que se caminhe no sentido de uma 
autêntica comunidade humana.

Mas, mesmo a respeito do trabalho associado, diz Marx que esta é a forma mais livre possível do trabalho, mas ainda não é a forma mais elevada possível da liberdade humana. Segundo ele, é para além do trabalho que está a forma mais elevada da liberdade. A autêntica comunidade humana é uma unidade que se perfaz na base do trabalho associado, que é o reino da necessidade, e do tempo livre, que é o reino da liberdade. Frisamos que reino da necessidade não é o reino da carência, não é o reino da miséria, não é o reino da falta de desenvolvimento, da falta de riqueza. Reino da necessidade é o reino do trabalho sempre. Por que isso? Porque o trabalho é sempre uma relação do homem com a natureza, e a natureza tem certas leis que precisam ser respeitadas. Não se pode transformar uma montanha de minério de ferro em aço se não se respeitarem certas leis. Mesmo que o trabalho seja feito em condições dignas, humanas, livres, escolhidas, prazerosas, mesmo aí ele tem respeitar certas leis da natureza. Este é o limite dele.

Este trabalho, realizado nestas condições dignas, humanas, onde a energia de todos é colocada em comum e permanece em comum sempre, este é o trabalho mais livre possível. Este trabalho permite criar riqueza em quantidade e qualidade adequadas para todo mundo e num tempo muito menor do que o de hoje. Não será necessário trabalhar seis dias por semana. Até no capitalismo já seria possível. Só que o capitalismo não pode deixar trabalhar menos porque senão as mercadorias baixariam tanto de valor que os capitalistas não ganhariam mais dinheiro. Não é por que não seria possível do ponto de vista científico e tecnológico. Se todo mundo fosse trazido para trabalhar, a quantidade de riqueza que poderia ser produzida seria tanta que seria possível produzir com um preço muito baixo. Aí os capitalistas não iam ganhar dinheiro. Veja-se a perversidade do capitalismo. Ele precisa da escassez, não é que ele não possa, por falta de tecnologia, superar a escassez, ele precisa da escassez para se manter.

Voltamos então à Ideologia Alemã. Lá Marx diz que no comunismo, depois de todo o trabalho necessário para produzir a riqueza suficiente para todos, sobra muito tempo livre. Aí, diz ele: pode-se caçar de manhã, pescar de tarde e fazer crítica literária de noite. É evidente que isso era um exemplo. Mas tem até muitos marxistas que afirmam que isto é coisa do século XIX, que isso não faz nenhum sentido hoje. É claro que faz sentido. Produzida a riqueza necessária e suficiente em pouco tempo, no restante do tempo, as pessoas poderão dedicar-se àquilo que é mais 
especificamente humano. Desenvolver atividades artísticas, científicas, filosóficas, lúdicas etc. Animal nenhum faz arte. Só os humanos fazem arte. Isto é especificamente humano. Aí está a autêntica liberdade humana. Liberdade é uma categoria importante, mas muito mal compreendida. Liberdade é autodeterminação e autodeterminação só pode ser coletiva.

Liberdade só pode existir onde sejam os indivíduos humanos a dirigir o processo social. Mas esta regência do processo social só pode existir quando houver uma base material que permita isso. A solidariedade nos diz muito claramente isso. Faz dois mil anos que o cristianismo prega o amor ao próximo. E, ainda sim, por que não se ama 0 próximo? Porque em uma sociedade onde há exploração do homem pelo homem não é possível; por que a realidade material impede isso. Ela nos faz todos opostos uns aos outros, nos faz concorrentes uns dos outros. Nessa situação, a solidariedade pode até aparecer como uma aspiração generosa, como atos isolados, mas não pode passar daí.

Aí entra o importante problema da ética. Para compreender melhor essa questão, permitimo-nos sugerir a leitura de um artigo nosso, publicado numa coletânea intitulada Contra o pragmatismo e a favor da filosofia da práxis. Nele procuramos mostrar que não é possível haver uma ética no capitalismo, porque ética são valores universais, que não podem se tornar realidade cotidiana no capitalismo, uma vez que nós somos opostos uns aos outros.

Para finalizar esta parte e entrar na Educação. Emancipação humana necessariamente implica a superação radical do capital e de todas as suas categorias: trabalho assalariado, valor de troca, mercadoria, dinheiro, classes sociais, Estado, cidadania, democracia, etc. Observe-se, porém, que não estamos dizendo que é para jogar fora estas últimas duas categorias. Não estamos menosprezando. Elas têm um grande valor, mas também têm um limite inultrapassável. É preciso construir uma liberdade humana superior à liberdade político-jurídica, a famosa emancipação política. Esta é a liberdade da emancipação humana.

Mas, o que tem tudo isso a ver com a Educação?

Primeiro, parece-nos claro que não dá para trabalhar para formar cidadãos. Em sã consciência, quem entende o que é cidadania não pode trabalhar para formar cidadãos, no sentido de colocar isto como horizonte e no sentido de que isto poderia ser ampliado indefinidamente. Não estamos dizendo que não se deve lutar por direitos civis, políticos e sociais. Estamos dizendo que é importante, que se deve lutar, 
sim, porque isto é uma forma de resistência da classe trabalhadora ao capital. O que estamos querendo enfatizar é que isto tem um limite inultrapassável e que não leva à superação da exploração do homem pelo homem.

$E$, dada a situação em que a humanidade se encontra hoje, o horizonte de nossas atividades no âmbito da Educação tem que ser a emancipação humana e não a cidadania. Por um motivo muito simples, voltamos àquela questão: a classe trabalhadora, os indivíduos que pertencem à classe trabalhadora, que são os indivíduos que produzem as riquezas. Para que esses indivíduos possam se tornar efetivamente membros do gênero humano na sua plenitude possível hoje, só há uma condição: acabar com o capitalismo (capitalismo-capital entenda-se tudo isso sempre junto). Acabar com esta forma de sociabilidade que os põe como trabalhadores que produzem a riqueza e que são impedidos de se apropriar dela pela forma da relação entre capitalista e trabalhador. Não há outra saída, simplesmente não há. Se pensamos em formação humana integral, se queremos uma formação humana integral, temos que ser sérios. Formação humana integral só é possível para além do capital, para aquém não dá.

Falar em formação humana integral; que temos que ter uma Educação integral do homem hoje, o que é isto? O trabalhador está sendo desumanizado praticamente, está sendo expropriado de sua humanidade. Como se pode falar em formação humana integral numa situação dessas? É preciso dar o devido peso a esse conceito e não utilizá-lo de forma superficial e irresponsável. Formação humana integral implica a apropriação do patrimônio, material e espiritual, à disposição da humanidade hoje, necessário à nossa configuração como indivíduos pertencentes ao gênero humano. Nenhum indivíduo pode apropriar-se adequadamente desses valores na sociedade capitalista, muito menos os trabalhadores. Portanto, falar em formação humana integral sem mostrar quais as condições para essa formação e sem mostrar a necessidade de se engajar na superação radical do capital é no mínimo enganar as pessoas.

Chegamos, então, à nossa última tese. Pensamos nós, e sabemos que isso é polêmico, mas é da boa polêmica que se faz uma boa universidade, que não podemos pensar em uma Educação emancipadora, numa política educacional emancipadora. $O$ que podemos fazer hoje - estamos falando na quadra histórica que desenhamos no começo - é um conjunto de atividades educativas emancipadoras, de caráter revolucionário. 
Entendemos que essa distinção entre educação emancipadora e atividades educativas emancipadoras é muito importante.

Quando falamos em Educação, pensamos num sistema mais geral, numa política educacional. Quando nos referimos a atividades educativas, pensamos em ações mais pontuais, mais limitadas. É neste sentido que afirmamos que não é possível, hoje, desenvolver uma Educação emancipadora, mas apenas atividades educativas de caráter emancipatório.

Isto porque a Educação sempre será hegemonizada pelas classes dominantes. Isto é absolutamente necessário para a reprodução da dominação dessas classes. Contudo, a sociedade capitalista não é homogênea. Ela é contraditória; ela não pode simplesmente reproduzir a si mesma sem deixar esses buracos, esses espaços. São essas contradições que permitem, embora de modo limitado, a realização de atividades educativas de caráter emancipatório.

Isto parece que fica até mais claro na própria realidade cotidiana. É nos sistemas públicos, no setor público que nós temos mais estes espaços Nas universidades federais temos muito mais espaço do que nas universidades particulares porque nessas últimas o domínio do capital é mais direto. Em cada canto o espaço é diferente, mas certamente há espaços.

Por isso mesmo, entendemos que pensar em uma política educacional, em uma Educação, no sentido mais geral, emancipadora é querer algo sem ter uma base real. Não basta querer algo, é preciso que esse algo possa ser traduzido em atividades reais. E o que pode se tornar real no sentido da emancipação humana são atividades pontuais, não o conjunto da Educação. Nesse sentido, muita coisa pode ser feita. $O$ problema é que as pessoas querem fazer coisas grandiosas e esquecem daquilo que é possível, mesmo sendo coisas pequenas.

O que nós podemos fazer, cada professor, cada estudante, porque os estudantes também têm que assumir essas tarefas, são atividades educativas cotidianas na direção da emancipação humana. Nós temos determinados espaços. O professor, na sua sala de aula, junto a seus alunos, pode escolher textos, escolher livros, promover determinados eventos.

Em favor das atividades educativas de caráter emancipador e não de uma Educação emancipadora há, ainda, o fato de que a Educação não é o carro-chefe da revolução. A Educação nunca foi e nunca será a locomotiva da transformação social. Ela pode contribuir para isso, mas não encabeçar o processo. E para agravar o quadro, 
na situação em que nos encontramos hoje, em que a classe trabalhadora não está se movendo, está cooptada, está profundamente alienada, não adianta querer uma Educação de caráter revolucionário no sentido mais geral. Se a conjuntura mudar e a classe trabalhadora começar a se mexer no sentido de assumir esta tarefa revolucionária contra o capital, certamente a coisa vai se tensionar no sentido de obrigar professores e alunos a tomar posições. E assim o processo vai se tornar mais intenso e mais dinâmico.

Se isto é verdade, então diríamos, para finalizar, que são necessários alguns requisitos, porque não basta querer virar revolucionário, não é suficiente ter disposição. A primeira coisa a fazer é estudar. É preciso compreender a realidade para poder transformá-la. Como disse uma vez Marx: a ignorância nunca ajudou ninguém. Contudo, muitas pessoas dizem: porque só ficar fazendo teoria; é preciso ir à prática! Esquecem que a prática sem a teoria é cego guiando cego. Ambos caindo no abismo. É claro que não se trata de fazer toda a teoria primeiro para depois ir para à prática. Esse não é o processo. É preciso começar iluminando a prática; tem que ter teoria para começar a iluminar; da prática volta-se à teoria, para ampliá-la, para de novo melhorar a prática; esse é o processo real, não primeiro todo um, depois todo o outro. Mas muita gente se esconde atrás do discurso da importância da prática para não precisar estudar, porque estudar exige esforço, exige paciência e não dá resultados grandiosos e imediatos.

Então, a primeira coisa é ter clara a natureza da emancipação humana. Para lutar por ela é preciso ter clareza do que se trata. E, para ter claro isso, faz-se necessária uma teoria do ser social que sustente tudo isso, pois deve se tratar de convicções solidamente sustentadas. Não se trata de fé; trata-se de sustentação racional. É preciso poder sustentar que a emancipação humana é possível e para isto são necessários argumentos sólidos. Mas, para saber o que é a emancipação humana tem que saber o que é o ser humano, o que é o processo histórico social, o que caracteriza esse processo histórico social. $\mathrm{E}$ a menos que alguém consiga por osmose ou por alguma revelação de alguma entidade, isso só pode vir através de um estudo muito sério e muito penoso. Penoso no sentido de que vai exigir um tempo e um esforço muito grande. É certamente muito gratificante, muito gostoso, muito prazeroso fazer isto, mas tem que dedicar um tempo grande. Quem não quer fazer isto não pode ficar falando de revolução e de emancipação humana. 
Segundo, é preciso que conhecer a dinâmica do capitalismo, conhecer a base material desta sociedade. Não dá para querer superar o capitalismo sem conhecê-lo. E isto certamente significa um esforço muito grande. E para isso o estudo da obra de Marx é imprescindível. Mesmo assim, isso ainda não é suficiente. Certamente, o que Marx disse, em O Capital e em outras obras, continua, em sua grande maioria, de enorme atualidade, mas não está tudo lá, nem poderia. A base está lá, mas depois de Marx aconteceu muita coisa; o mundo mudou muito. O próprio capitalismo de hoje é muito diferente daquele do tempo de Marx. Por isso, não basta conhecer a lógica mais essencial do capital. Isso certamente é fundamental. Mas, além disso, temos que conhecer a história do capitalismo e o que está acontecendo hoje, a crise atual.

Além disso, além de conhecer a realidade histórica do capitalismo na sua natureza dinâmica, na sua lógica mais profunda e no seu desdobramento histórico e na atual crise, é preciso saber o que é a Educação. Não dá para simplesmente querer educar no sentido muito genérico. É preciso saber o que é educação no sentido muito preciso e para isso é necessária, de novo, uma teoria geral do ser social, uma ontologia do ser social. Ela nos permite entender o que é este ato humano que se chama Educação. Sem poder entrar em detalhes, aqui, sinalizo que é preciso saber como é que a Educação se gera histórico-ontologicamente, qual é a natureza e a função social dela. Isso para nem subestimar e nem superestimar a importância dela no processo social.

Mas isso não basta. Também é preciso dominar os conteúdos que vão ser tratados. E nesse terreno a questão é muito séria, porque não basta falar em conteúdos no sentido geral. É preciso perguntar: de que conteúdo se trata?

Por exemplo, para quem vai ensinar Filosofia ou Sociologia. Não basta dominar o conteúdo destas disciplinas no sentido tradicional. É preciso perguntar: de que Filosofia e de que Sociologia se trata? Os conteúdos não são neutros. Numa sociedade de classes, os conteúdos têm uma forte determinação pelo viés das classes dominantes. Só para provocar: não há nada mais perdido do que a Filosofia hoje e a maioria da Sociologia é contrarrevolucionária. O velho Marx dizia na décima primeira tese ad Feuerbach: Os filósofos até hoje se preocuparam em interpretar o mundo; tratase de transformá-lo. Mas, os filósofos continuam apenas a interpretar o mundo. É preciso uma teoria, uma Filosofia e uma ciência que contribuam para conhecer o mundo até a sua raiz, que permitam visualizar a possibilidade de transformá-lo radicalmente, e tudo isto é o que a academia não faz. 
Voltamos àquela nossa provocação anterior. Marx instaurou um paradigma científico e filosófico radicalmente novo. Este paradigma instaurado é o que a humanidade tem à disposição de mais elevado em termos de instrumental de conhecimento. Mas, quem é que estuda Marx hoje? Isto é um problema. Se a afirmação acima é verdadeira, então temos que voltar a resgatar o velho Marx. Não tem saída, porque ele é o autor que mais contribui para que possamos conhecer a realidade e visualizar a possibilidade de superação desta forma de sociabilidade. Portanto, tem que haver uma Filosofia de caráter radicalmente revolucionário e essa Filosofia, essa ciência se chama, a nosso ver, ontologia do ser social.

Então, se eu sou filósofo, se eu vou ensinar Filosofia... Que filosofia? Não é simplesmente ensinar Filosofia. A maioria das filosofias é essencialmente contrarrevolucionária - existencialismo, fenomenologia, filosofia analítica, filosofia da mente, estruturalismo etc. Pergunte-se a elas, a essas teorias e a essas filosofias proeminentes hoje se elas propõem a superação radical do capital. Nenhuma delas propõe. Logo, se é verdade o que dissemos até agora, elas não estão do lado da revolução, não estão do lado da emancipação humana. Como só tem dois lados, não tem três, elas estão do lado da reprodução do capital, mesmo com a maior das boas intenções.

Não é só. Seria necessário fazer a crítica das Ciências Sociais. Porque não é qualquer Ciência Social, tem que ser uma ciência, uma filosofia de caráter ontológico. Porque esta é a ciência e a filosofia que vai à raiz e que permite sustentar uma outra forma de sociabilidade radicalmente diversa. Esta é a pedra de toque de qualquer filosofia e de qualquer ciência social. Se ela permite conhecer a realidade até a raiz e ultrapassar a imediaticidade a partir dessa raiz. E se ela está do lado de uma possibilidade racionalmente sustentada de transformação radical da ordem social.

Pra finalizar, então, vamos à prática também. Temos que nos engajar nas lutas sociais, tanto nas específicas quanto nas mais gerais. Essas lutas estão ocorrendo cotidianamente. Temos que entrar nelas. Há o momento da elaboração teórica e há o momento do engajamento nas lutas práticas. Esse engajamento é importante até para realimentar a nossa elaboração teórica. Enfim, embora a quadra esteja hoje muito difícil, muito complicada, é preciso participar das lutas sociais, tanto das especificas da Educação quanto das mais gerais, senão ficamos apenas fazendo uma parte. 


\section{CONSIDERAÇÕES FINAIS}

Voltando a resumir a questão, tentamos demonstrar que a cidadania e a democracia fazem parte da emancipação política; que são uma forma de liberdade que a humanidade conquistou e que tem o seu valor, que produziu bons frutos, mas que é essencialmente limitada, e que defender cidadania e democracia hoje como horizonte da humanidade é favorecer aburguesia.

Procuramos também mostrar que a emancipação humana é o patamar mais elevado possível da liberdade humana e que expressa uma forma de sociabilidade em que todos os seres humanos, todos os indivíduos podem se realizar como indivíduos humanos plenamente livres. Plenamente livres, e gostaríamos de acentuar essa categoria, deixando claro que plenamente livres não significa absolutamente livres, irrestritamente livres. Significa uma sociedade emancipada em que todos possam ter as bases materiais para reger o processo social e, portanto, porem-se como indivíduos efetivamente livres, que podem se autodeterminar coletivamente. E para finalizar tentamos fazer a articulação entre emancipação humana e Educação, deixando claro que nós podemos fazer atividades educativas revolucionárias dentro de nossa sala de aula, fora da nossa sala de aula, individualmente, em grupos, mas que não podemos pensar em uma Educação emancipadora dentro desta sociedade como algo generalizado. E finalmente procuramos deixar claro que qualquer atividade educativa que pretenda contribuir para a construção de indivíduos efetivamente livres, terá que perspectivar-se pela emancipação humana e não pela cidadania.

\section{REFERÊNCIAS}

CHAUÍ, M. Convite à filosofia. São Paulo. Ática, 1997.

JIMENEZ, S. et al (Org). Contra o pragmatismo e a favor da filosofia da práxis. Fortaleza, EdUECE, 2007.

MARX, K. O Capital. Rio de Janeiro, Civilização Brasileira, 1975.

. A questão judaica. São Paulo, Moraes, 1991.

. A Ideologia alemã. São Paulo, Hucitec, 1986.

. Manuscritos econômico-filosóficos. São Paulo, Boitempo, 2004.

. Glosas críticas ao artigo O Rei da Prússia e a Reforma Social. De um prussiano. In: Praxis. Belo Horizonte, Projeto Joaquim de Oliveira, 1995. 
PINSKY, J. e PINSKY, C. História da cidadania. São Paulo, Contexto, 2003.

TONET, I. Educação, cidadania e emancipação humana. ljuí, Unijuí, 2005. . Educação contra o capital. Maceió, Edufal, 2007. . Democracia ou liberdade. Maceió, Edufal, 2004. 